\title{
Analyzing and modelling effects of climate on site productivity of white spruce plantations
}

\author{
by Mahadev Sharma ${ }^{1 *}$ and John Parton²
}

\begin{abstract}
Effects of climate on site productivity of white spruce (Picea glauca) plantations were examined. Stem analysis data collected from 93 dominant or co-dominant white spruce trees sampled from 93 plots (1 tree/plot) in even-aged monospecific plantations on 31 sites (three plots/site) in the Canadian boreal forest region of Northern Ontario were used to examine effects of climate on site productivity and to develop stand height models. Site index was used as an estimate of site productivity. Effects of site and climate on site productivity were examined by regressing site index against site and climate variables. The site specific attributes explained $33 \%$ of the variability in site index for white spruce. Stand height models were then developed by incorporating climate variables. Climatic effects specifically those of projected increased warming and rainfall on stand height growth were evaluated by predicting stand heights for three randomly selected locations (in eastern, western, and southern Ontario) for the period 2041 to 2070 under three emissions trajectories. These trajectories are known as Representative Concentration Pathways (RCPs), with each reflecting different levels of heat at the end of the century (i.e., 8.5, 4.5, and 2.6 watts $\mathrm{m}^{-2}$ ). At the end of the 2041 to 2070 growth period under all three climate change scenarios, projected stand heights were shorter than those under the current climate. Under the 2.6 RCPs scenario, the difference in stand heights was more pronounced in the south (43.8\%) than in the east (38.2\%) and west (27.8\%) and under the other (4.5 and 8.5, respectively) RCPs scenarios, the difference was more pronounced in the east (58.9 and 74.4\%) and west (59.7 and 72.1\%) than in the south (51.5 and 64.6\%). The stand height models that were developed can be used to estimate stand heights for white spruce plantations in a changing climate. Using the same model, site index of a plot/stand can be estimated by calculating height at a given base (index) age. When climate data are not available, the model fitted without the climate variables can be applied to estimate stand heights and site indices.
\end{abstract}

Keywords: hierarchical clustered data, biophysical effects, stand height, dynamic models, climate change.

\section{RÉSUMÉ}

Cet article s'intéresse aux effets du climat sur la productivité des plantations dépinette blanche (Picea glauca). Les données qui ont servi à étudier les effets du climat sur la productivité des stations et à élaborer des modèles de hauteur de peuplements proviennent d’analyse de tige prélevées sur 93 tiges d'épinette blanche dominantes ou codominantes choisies dans 93 placettes ( 1 arbre par placette) dans des monocultures équiennes plantées sur 31 stations ( 3 placettes par emplacement) de la forêt boréale canadienne du nord de l'Ontario. Nous avons retenu indice de qualité de station comme mesure de productivité de la station. C'est en modélisant cet indice de qualité de station en fonction des variables de la station et du climat qu'il a été possible d’analyser les effets de la station et du climat sur la productivité de la station. Les paramètres de la station ont permis d'expliquer $33 \%$ de la variabilité de lindice de qualité de station pour lépinette blanche. Nous avons ensuite élaboré des modèles de hauteur de peuplement en intégrant les variables du climat. Nous avons ainsi pu évaluer les effets du climat, notamment ceux des hausses prévues de la température et des précipitations, sur la croissance en hauteur des peuplements en calculant les hauteurs de peuplements à trois endroits choisis au hasard (dans lest, louest et le sud de l'Ontario) pour la période de 2041 à 2070 en fonction de trois scénarios deémissions. Ces scénarios connus sous lacronyme RCP (Representative Concentration Pathways) représentent différentes trajectoires de forçage radiatif à la fin du siècle (c. à d. 8,5, 4,5, et 2,6 watts $\mathrm{m}^{-2}$ ). À la fin de la période de croissance de 2041 à 2070 et sous les trois scénarios de changement climatique, les hauteurs projetées étaient inférieures à celles qui seraient obtenues sous les conditions climatiques actuelles. Dans le scénario RPC 2,6, la différence de hauteur de peuplement était plus importante dans le Sud $(43,8 \%)$ que dans l'Est $(38,2 \%)$ et l'Ouest $(27,8 \%)$, et dans les autres scénarios RPC (4,5 et 8,5, respectivement) la différence était encore plus prononcée dans l'Est (58,9 et 74,4\%) et l'Ouest (59,7 et 72,1 \%) que dans le Sud (51,5 et 64,6 \%). Les modèles de hauteur de peuplement que nous avons élaborés peuvent servir à évaluer la hauteur de peuplement pour des plantations dépinette blanche en fonction des changements climatiques. Le même modèle peut aussi servir à évaluer l'indice de qualité de station d'une parcelle ou d'un peuplement en calculant la hauteur à une hauteur à la souche donnée. Lorsqu'il n'y a pas de données climatiques de disponibles, le modèle peut être ajusté pour estimer les hauteurs de peuplements et les indices de qualités de station sans tenir compte des variables du climat.

Mots-clés : regroupement hiérarchique des données, effets biophysiques, hauteur de peuplement, modèles dynamiques, changement climatique

\footnotetext{
${ }^{1}$ Ontario Forest Research Institute, Ministry of Natural Resources and Forestry, Sault Ste. Marie, ON P6A 2E5 ${ }^{\star}$ Corresponding author: mahadev.sharma@ontario.ca

${ }^{2}$ Ministry of Natural Resources and Forestry, South Porcupine, ON P0N 1H0
} 


\section{Introduction}

In forest management planning, site productivity can be described as the production potential of a given site for a particular tree species (Mamo and Sterba 2006). Therefore, the ability to measure site productivity is a critical prerequisite for accurately projecting forest growth and yield and wood supply. Site productivity depends on environmental factors that include biotic, edaphic, and climatic conditions (Clutter et al. 1983). Climatic effects are of particular interest since global average surface air temperature is projected to warm between 1.4 and $5.8^{\circ} \mathrm{C}$ by 2100 relative to 1990 (IPCC 2000). For the province of Ontario, Canada, based on the A2 scenario (IPCC 2000), summer temperatures are expected to rise by 3 to $6^{\circ} \mathrm{C}$ by the end of the 21 st century, with more pronounced differences in the north (Colombo et al. 2007).

The most common and well accepted method for measuring site productivity is to develop stand height-age relationships (Vanclay 1994) and estimate the site index (SI), which is defined as the average height of dominant and co-dominant trees (stand height) at a specified (index) age (Sharma et al. 2002). Site productivity could be influenced by changes in climate that affect tree growth, which would affect predictions of stand and forest volume, biomass, carbon content, and wood supply.

Sharma et al. (2015) analyzed climatic effects on site productivity of jack pine (Pinus banksiana Lamb.) and black spruce (Picea mariana (Mill.) BSP) plantations. To account for the effects of expected changes in climate on site productivity of these tree species, they developed stand height/SI models that included climate variables. They reported that projected changes in climate would reduce site productivity of both species, with greater effects on black spruce than jack pine. In another study, Sharma and Parton (In press) found that the site productivity of red pine (Pinus resinosa Ait.) was also projected to be negatively affected by projected changes in climate. The climatic effects were expected to be more pronounced in southern than in northern Ontario. These climate sensitive stand height/SI models are being used in developing predictive models such as benchmark yield curves, density management diagrams, and tree-scale models (forest vegetation simulator FVS ${ }^{\text {Ontario }}$ ). Since outputs from these growth and yield models feed broader scale models such as the carbon accounting models FORCARB (Forest Carbon Budget Model) and CBM-CFS3 (Carbon Budget Model of the Canadian Forest Sector) and the forest management planning models MIST (Model and Inventory Support Tool) and SFMM (Sustainable Forest Management Model), the benefits of improved SI models cascades through the hierarchy of models used in Ontario.

The objectives of this study were to investigate the effects of climate on the SI and stand height of white spruce (Picea glauca (Moench) Voss) plantations over time. For this purpose, we first examined which variables affected SI of white spruce plantations in our study area and then incorporated these climate variables into a stand height trajectory model using a nonlinear mixed-effects model (Littell et al. 2006) and a parameter prediction approach.

\section{Materials and Methods \\ Height and age data}

Data used in this study were collected from plantation-grown white spruce trees in 31 even-aged monospecific plantations from across Ontario (Fig. 1). The UTM coordinates of these plantations ranged from 294513 to $720844 \mathrm{E}$ and 4902171 to $5631299 \mathrm{~N}$. Within each plantation, three $100 \mathrm{~m}^{2}$ circular sample plots were established. In each plot, one planted, largest diameter (at breast height) non-veteran tree with no visible deformities such as forks, major stem injuries, dead or broken tops was selected. For each tree selected, disks were cut at $0.15,0.5,0.9$, and $1.3 \mathrm{~m}$ from the ground. The remaining height of the tree (between breast height and tip) was divided into 10 equal segments with disks taken at the top of each segment resulting in 13 disks per tree.

Each sample tree and disk was assigned a unique code. All disks from a tree were placed in a large breathable bag, transported, and stored at $-10{ }^{\circ} \mathrm{C}$ until 24 hours before they were prepared for analysis, which involved sanding the surface of the disk. At the time of analysis, the geometric mean radius (r) was calculated from the diameters obtained from the major $\left(r_{1}\right)$ and minor $\left(r_{2}\right)$ axes on each disk (i.e., $\left.r=\left(r_{1} \cdot r_{2}\right)^{0.5}\right)$. On each section, two radii matching this geometric mean were located and marked. All disks were scanned and ring counts were made with WINDENDRO ${ }^{\mathrm{TM}}$ software (Regent Instruments Inc., Montreal, Quebec) along two radii marked from the pith of each disk. If the ring counts along these two radii from pith onwards did not match, the larger ring count was used.

Tree height at a given age along the bole was determined using Graves' (1906) method, which Subedi and Sharma (2010) reported as being more accurate than other available methods for identifying where annual height growth ended. Since only 13 disks were sampled from a tree and the minimum age of sampled trees was 42 years, on average more than three annual height growths ended between any two consecutive disks sampled. Therefore, the total height at the end of each growing season that fell between any two consecutive disks along the bole was calculated based on the ring counts and the disk heights from the ground using the Graves' (1906) method for each tree. The total height at the end of each growing season that occurred after the last $\left(13^{\text {th }}\right)$ disk was calculated based on the ring counts on this disk and the tip of the tree where the ring count was zero.

Observed stand heights and ages were plotted to form height-age curves for each tree. These curves were inspected for indications of early height growth suppression, top breakage, or dieback. None of the trees sampled showed any defects. Therefore, data from all 93 trees were used in the analysis. To avoid the erratic height growth that often occurs before trees reach breast height, height above breast height and breast height age (BHA) were used in this study. Therefore, unless otherwise specified, in this paper all heights and ages refer to stand heights from breast height and BHAs, respectively.

To obtain site-level observations of stand height, growth series from each plot were averaged to provide a mean plot 


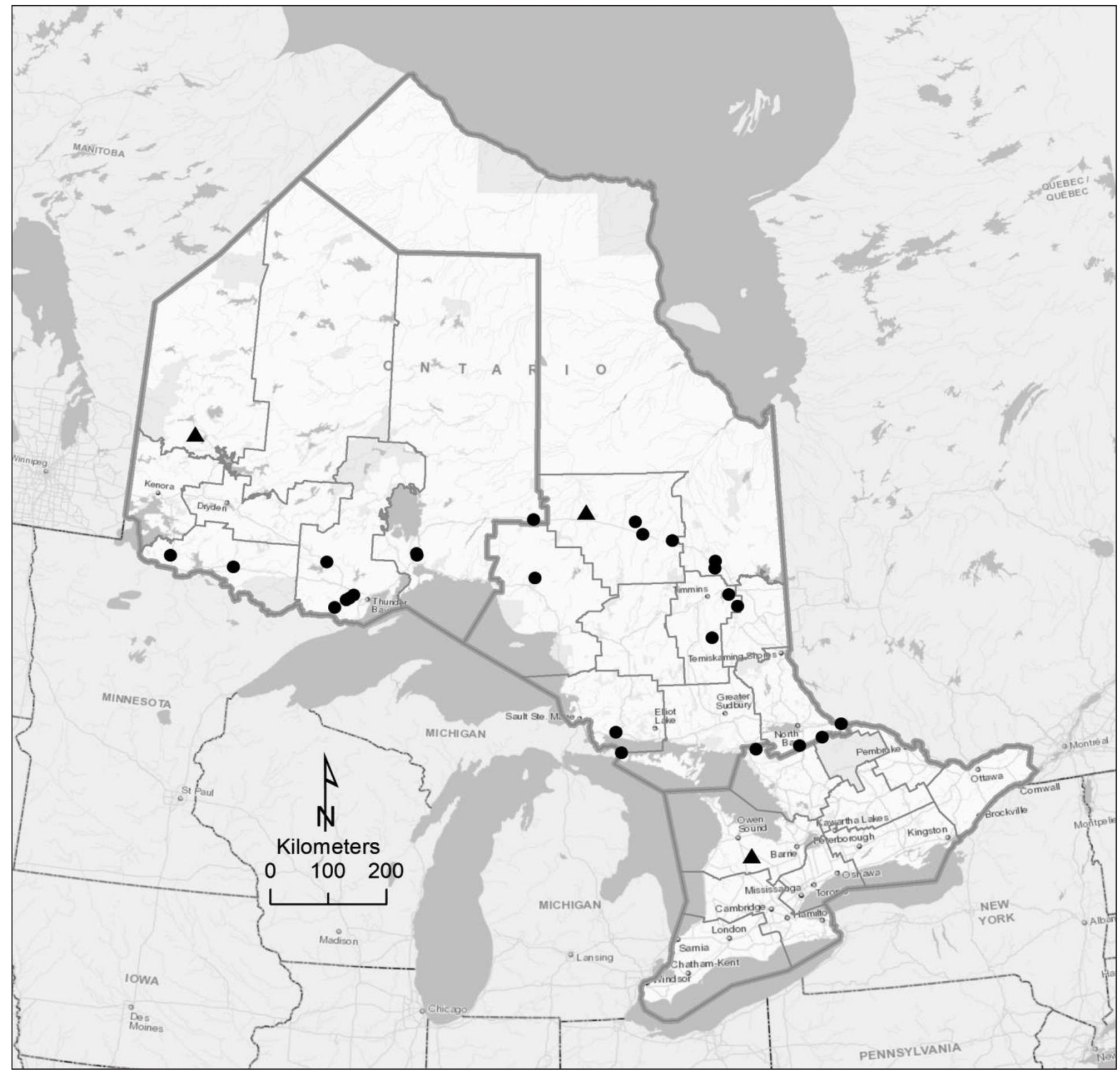

Fig. 1. Distribution of white spruce plantation sample sites across Ontario. Triangles represent sites that include the randomly selected evaluation plots.

growth curve. For plots that contained trees of different ages, series were truncated to the age of the youngest tree. This resulted in 31 total height-age series. For each series, average height was calculated at every five-year non-overlapping interval starting at age one (from breast height) to minimize the serial autocorrelation among observations and measurement errors in the ring data. If the last observation of a growth series turned out to be less than five years apart from its previous counterpart, that observation was discarded.
Similarly, site index was calculated as the average height of three dominant/codominant trees sampled from a site at BHA 25 years. Summary statistics for diameter at breast height $(\mathrm{DBH})$ and total height of sampled trees are presented in Table 1.

\section{Climate data}

None of the plot locations were near weather stations. Therefore, Canadian climate models (McKenney et al. 2011) were 
Table 1. Summary statistics ( $\mathrm{N}=$ =number of samples; $\mathrm{SD}=$ standard deviation) for total height, diameter at breast height (DBH), total age, breast height age (BHA), site index (SI) and climate and site related variables (warmest quarter mean temperature (WQMT), warmest quarter total precipitation (WQTP), annual maximum temperature (AMT), and elevation (ELV); the climate variables are average values calculated using the period 1971 to 2013

\begin{tabular}{lccccc}
\hline Variable & N & Mean & SD & Min & Max \\
\hline Height (m) & 93 & 20.98 & 2.91 & 15.25 & 29.35 \\
DBH $(\mathrm{cm})$ & 93 & 29.97 & 6.67 & 16.30 & 52.90 \\
Total age (year) & 93 & 55.62 & 10.26 & 42.00 & 87.00 \\
BHA (year) & 93 & 49.86 & 10.18 & 35.00 & 82.00 \\
SI (m) & 31 & 10.78 & 1.68 & 7.14 & 13.92 \\
WQMT $\left({ }^{\circ} \mathrm{C}\right)$ & 31 & 16.4 & 0.9 & 14.9 & 17.8 \\
WQTP $(\mathrm{mm})$ & 31 & 260 & 16 & 229 & 292 \\
AMT $\left({ }^{\circ} \mathrm{C}\right)$ & 31 & 8.1 & 1.4 & 6.1 & 10.3 \\
ELV $(\mathrm{m})$ & 31 & 302 & 79 & 177 & 456 \\
\hline
\end{tabular}

used to estimate a suite of climate variables for each plot location. These models were generated from continuous climate grids using ANUSPLINE based on corrected Canadian weather station data (Mekis and Vincent 2011; Vincent et al. 2012), which includes many stations in Ontario. Estimates of long-term average values of these variables at each plot location were calculated for the period 1971 to 2013.

A total of 68 variables were calculated, including mean, minimum, and maximum air temperatures and total precipitation, estimated for each month of the year, for each quarter (consecutive three month periods), and annually. As well, estimates for start, end, and length of the growing season and the sum of growing degree days using a base temperature of 5 ${ }^{\circ} \mathrm{C}$ were included in the climate data. Growing season was defined as the length of time between the day after March 1 when mean daily temperature was $\geq 5^{\circ} \mathrm{C}$ for five consecutive days and the day after August 1 when minimum daily temperature was $\leq-2{ }^{\circ} \mathrm{C}$. Estimates for the above variables were provided by Dan McKenney (Canadian Forest Service). The 68 variables also included three site-related variables (longitude, latitude, and elevation).

\section{Effects of climate on site productivity}

Climatic effects on site productivity were determined by regressing SI against climate variables. In this case, SI was defined as the average height of three dominant trees sampled from a plantation (site) at BHA 25 (index age). The stepwise regression method was applied in SAS (SAS Institute Inc. 2004) using FORWARD, BACKWARD, and MAXR (maximum $\mathrm{R}^{2}$ ) selection criteria to examine the importance of each site and climate variable in the regression. However, BACKWARD selection resulted in better fit statistics than other criteria. Given the limited number of SI values (31), climate variables were grouped into site, periodic temperature, periodic precipitation, monthly temperature, and monthly precipitation related variables. SI was regressed against the site and climate variables within a group and variables significant from each group were pooled together. Finally, SI was regressed against pooled site and climate variables.

\section{Stand height/site index models}

Changes in the average height of dominant and co-dominant trees over time are generally described using nonlinear mathematical models. These models are often derived from simpler, single-curve models, which can be exponential or fractional functions (Cieszewski 2003). The most common exponential model used to describe height development over time is the Chapman-Richards growth function (see Burkhart and Tennent 1977, Carmean and Lenthall 1989, Goelz and Burk 1992, Garcia 2005). Similarly, the fractional function most suited to developing SI models is Hossfeld IV (Cieszewski 2003). Therefore, Chapman-Richards and Hossfeld IV functions were considered as models from which to derive SI models.

Several variants of these two functions were evaluated using the study data sets but the following variant of the Hossfeld IV function, also known as McDill-Amateis growth function (see Burkhart and Tome 2012), resulted in the best fit (in terms of $\mathrm{R}^{2}$ and MSE) and the most consistent and biologically realistic height estimates across productivity classes:

$$
\text { (1) } H=\frac{\alpha_{0}}{1-\left[\frac{1-\frac{\alpha_{0}}{H_{1}}}{A}\right]\left[\frac{A_{1}}{A}\right]^{\alpha_{1}}}
$$

Where $H$ and $H_{1}$ are stand heights (from breast height) at BHAs $A$ and $A_{1}$, respectively, and $\alpha_{0}$ and $\alpha_{1}$ are model parameters. In general, $\alpha_{0}$ defines the asymptote of the curve and $\alpha_{1}$ determines the shape. Therefore, this model form was chosen as the height growth model for this study. To model the effects of climate on height growth, the asymptote and rate parameter $\left(\alpha_{0}\right.$ and $\alpha_{1}$, respectively) in Eq. (1) were expressed in terms of climate variables.

\section{Model fitting and evaluation}

The data used in this study originated from stem analysis. Height-age series for a site were obtained by multiple measurements on individual trees sampled from the site, resulting in hierarchical data sets (i.e., height-age series within sites). As a result, two sources of variation exist, among sites and within a site. Observations among sites are independent but observations within a site (height-age series) are dependent (correlated) as they originate from the same trees. The autocorrelation problem within a sampling unit can be addressed by using the mixed-effects modelling technique (Meng et al. 2009; Subedi and Sharma 2011, 2013), correlation structure (Diéguez-Aranda et al. 2006), or a combination of both (Trincado and Burkhart 2006; Subedi and Sharma 2013).

Equation (1) contains stand heights $H$ and $H_{1}$ corresponding to BHAs $A$ and $A_{1}$, respectively, where $H$ is the dependent variable and the rest are independent variables. To fit this equation, the data was structured to contain vectors of $H, H_{1}$, $A$ and $A_{1}$ for every site. In this case, $H$ is the vector of stand height values at every fifth year starting at BHA 6, i.e., stand heights at BHAs $6,11,16,21, \ldots$ Similarly, $H_{1}$ is the vector of stand height values at every fifth year starting at BHA 1, i.e., stand height values at BHAs 1, 6, 11, 16, .. For every observation, $A$ is always five years greater than $A_{1}$. Similarly, within a growth series every two consecutive observations are exactly five years apart. 
Equation (1) was first fitted to the data set using NLMIXED procedure in SAS. Initially all precipitation related variables were introduced into the model one by one. The variable that was significant $(\mathrm{alpha}=0.05)$ and resulted in the best fit was selected as the first climate (precipitation) variable to be incorporated in the model. All temperature related variables were then introduced into the model one by one in the presence of the first climate (precipitation) variable. The one that was significant and resulted in the least AIC value was selected as the second climate (temperature) variable to be incorporated. All the other climate and site variables including quadratic transformations and two-way interactions were introduced one by one in the presence of the first two climate variables. The climate and site variables selected were those that were both significant and improved model fit.

The model with climate variables was then fitted using the mixed-effects modelling approach in SAS. Random-effects parameters were added to the fixed-effects coefficients as long as they were significant. The model with random effects was evaluated based on goodness-of-fit criteria such as log-likelihood (twice the negative log-likelihood) ratio, assessment of model residuals, and Akaike's Information Criterion (AIC; Akaike 1978). The model with the smallest goodness-of-fit value was considered best. Pseudo $\mathrm{R}^{2}$ defined as (model sum of squares - mean sum of squares)/(total sum of squares mean sum of squares) of stand height was also calculated to check the goodness-of-fit. To address problems associated with autocorrelation, the model with climate variables was fitted with $\mathrm{AR}(1)$ covariance structure. To check possible heteroscedasticity, estimates of residuals (observed - predicted) from stand height were calculated (with the covariance structure in the model) for all stand heights for every fifth year for each growth series and plotted against the predicted stand height.

\section{Results and Discussion}

The stepwise regression of SI against site and climate variables using BACKWARD selection criteria revealed 17 of the latter were significant in explaining the variability in SI. However, most of these variables were highly correlated. Interpretation of results from highly correlated dependent variables could be misleading. Therefore, climate and site variables that are not highly correlated and significant in the regression were investigated. The variables that were not highly correlated and explained the most variation in SI were selected. Three climate and one site variables - warmest quarter mean temperature (WQMT), warmest quarter total precipitation (WQTP), annual maximum temperature (AMT), and elevation (ELV) - were significant in the regression and explained 33\% of the variation in SI. The correlation among these variables was negligible as the variance inflation factor (VIF) for all variables was less than five. These results indicate that the SI of white spruce is significantly affected by climate. Summary statistics for these climate variables are provided in Table 1.

Parameter estimates for Eq. (1) fitted using NLMIXED procedure in SAS are displayed in Table 2. The model fits the data well but does not include climate variables. Since issues related to possible heteroscedasticity and autocorrelation were not analyzed in fitting Eq. (1), the p-values of parameter estimates $(<0.0001)$ and other fit statistics are approximate. To include climate variables in Eq. (1), the asymptote and rate
Table 2. Parameter estimates, standard errors (SE), and fit statistics (MSE, twice the negative log-likelihood (-2hn(L)], Akaike's Information Criterion (AIC) for the model without climate variables Equation (1) for white spruce trees from Northern Ontario

\begin{tabular}{lrr}
\hline Parameters & Estimates & SE \\
\hline $\boldsymbol{\alpha}_{0}$ & 48.1948 & 3.0739 \\
$\boldsymbol{\alpha}_{\boldsymbol{1}}$ & 1.2445 & 0.0236 \\
MSE & 0.1728 & - \\
$-\mathbf{2 L n}(\mathrm{L})$ & 276.0 & - \\
AIC & 282.0 & - \\
Total DF & 255 & - \\
Residual DF & 252 & - \\
\hline
\end{tabular}

parameter $\left(\alpha_{0}\right.$ and $\alpha_{1}$, respectively) were expressed in terms of climate variables using a parameter prediction approach. The climate variables that were significant (alpha $=0.05)$ in explaining the variation in stand height of dominant and codominant white spruce trees were warmest quarter mean temperature (WQMT) and warmest quarter total precipitation (WQTP). Both the asymptote and the rate parameter, expressed as a linear function of these climate variables, resulted in the best model. The correlation between WQMT and WQTP was very small $(0.1813)$ and not significant $(\mathrm{p}=$ 0.329 ). Therefore, the model form that included climate variables was:

(2) $\mathrm{H}=\frac{\beta_{0}+\beta_{1} W Q M T+\beta_{2} W Q T P}{1-\left[1-\frac{\beta_{0}+\beta_{1} W Q M T+\beta_{2} W Q T P}{H_{1}}\right]\left[\frac{A_{1}}{A}\right]^{\beta_{3}+\beta_{4} W Q M T+\beta_{5} W Q T P}}+\varepsilon$

Where $\beta_{0}-\beta_{5}$ are parameters and other variables are as defined earlier. Both intercepts of the linear expressions for the asymptote and rate parameter were positive. In the presence of WQTP, the coefficient of WQMT was positive for the asymptote and negative for the rate parameter. On the other hand, the coefficient of WQTP was negative for the asymptote and positive for the rate parameter in the presence of WQMT (Table 3). This indicates that an increase in WQMT would increase the asymptote (the maximum potential height) but decrease height growth rate in the presence of WQTP. Similarly, the increase in WQTP would decrease the asymptote but increase height growth rate in the presence of WQMT.

When climate variables were included in the model, the fit statistics ( -2 log-likelihood and AIC) decreased (Tables 2 and 3). Thus, Eq. (2) not only incorporated climate variables but also improved fit statistics. As a result, Eq. (2) could be used to explain the effects of climate on stand height growth for white spruce plantations. Random-effects parameters and autocorrelation were added to the fixed-effects coefficients but none of the models with random effects and/or autocorrelation could be fitted using NLMIXED. Therefore, NLINMIX macro was used to fit these models. However, the models with random effects did not converge using the macro also 
Table 3. Parameter estimates (standard errors in parentheses), and fit statistics, MSE, twice the negative log-likelihood (2ln(L), Akaike's Information Criterion (AIC), and degrees of freedom (DF) for the model with climate variables (Equation (2) with and without autocorrelation) for white spruce from Northern Ontario

\begin{tabular}{lrr}
\hline Parameters & Equation (2) & $\begin{array}{r}\text { Equation (2) with } \\
\text { autocorrelation }\end{array}$ \\
\hline $\boldsymbol{\beta}_{\mathbf{0}}$ & $21.6428(6.1869)$ & $18.4296(8.4693)$ \\
$\boldsymbol{\beta}_{\boldsymbol{1}}$ & $16.6312(3.7344)$ & $16.5835(5.0671)$ \\
$\boldsymbol{\beta}_{\mathbf{2}}$ & $-0.9226(0.1377)$ & $-0.9055(0.1908)$ \\
$\boldsymbol{\beta}_{3}$ & $1.4266(0.4807)$ & $1.5989(0.5106)$ \\
$\boldsymbol{\beta}_{4}$ & $-0.07531(0.0203)$ & $-0.0805(0.0266)$ \\
$\boldsymbol{\beta}_{5}$ & $0.004062(0.0010)$ & $0.003668(0.0013)$ \\
$\mathbf{M S E}$ & 0.1541 & 0.1566 \\
$\boldsymbol{\rho}$ & - & 0.4200 \\
$-\boldsymbol{2} \boldsymbol{L n}(\boldsymbol{L})$ & 261.7 & 218.2 \\
$\boldsymbol{A I C}$ & 263.7 & 222.2 \\
\hline
\end{tabular}

${ }^{*}$ All parameter estimates were statistically significant $(\mathrm{p}<0.01)$

indicating that the additional random effects were probably not needed. Both climate variables were significant (alpha $=0.05)$ and all the model coefficients had the same signs (positive or negative) as those estimated without $\mathrm{AR}(1)$ (Table 3). The first order autoregressive autocorrelation structure $(\rho)$ indicated that the model error terms were positively correlated with the residual of prediction from the previous period. As far as the heteroscedasticity is concerned, residual plot did not suggest any signs of heteroscedasticity (Fig. 2).

Equation (2) was further evaluated by calculating the mean difference between measured and estimated heights, hereafter termed "bias". Residuals (observed - predicted) in
Table 4. Bias (observed - predicted) and its standard deviation (Stdev) of the residuals from fitting equations (1) and (3) for white spruce in Northern Ontario by height and age class

\begin{tabular}{lccccc}
\hline & & \multicolumn{2}{c}{ Equation (1) } & \multicolumn{2}{c}{ Equation (2) } \\
\cline { 3 - 6 } $\begin{array}{l}\text { Height } \\
\text { class }(\mathbf{m})\end{array}$ & $\mathbf{N}$ & Bias & Stdev & Bias & Stdev \\
\hline $0-5$ & 30 & -0.0637 & 0.3708 & -0.0207 & 0.3599 \\
$5-10$ & 68 & 0.0112 & 0.4167 & 0.0299 & 0.4081 \\
$10-15$ & 78 & 0.0993 & 0.5128 & 0.0537 & 0.4084 \\
$15-20$ & 61 & 0.0384 & 0.3344 & 0.0188 & 0.3459 \\
$>20$ & 18 & -0.0448 & 0.1644 & -0.0855 & 0.1552 \\
& & & & & \\
Age class (yr) & & & & & \\
$<10$ & 31 & -0.1193 & 0.3964 & -0.0769 & 0.3492 \\
$10-20$ & 62 & 0.0191 & 0.4251 & 0.0594 & 0.4006 \\
$20-30$ & 62 & 0.0757 & 0.4752 & 0.0623 & 0.3976 \\
$30-40$ & 56 & 0.0968 & 0.3986 & 0.1068 & 0.3857 \\
$40-50$ & 28 & 0.0385 & 0.3525 & 0.0192 & 0.3687 \\
$50-60$ & 11 & -0.0357 & 0.3042 & -0.0167 & 0.3439 \\
$60-70$ & 3 & -0.0946 & 0.2279 & -0.0713 & 0.1503 \\
$>70$ & 2 & 0.0645 & 0.0420 & -0.0978 & 0.0273 \\
\hline
\end{tabular}

predicting the stand heights were obtained and bias (average residual) and its standard deviation were calculated for each height and age class (Table 4). For comparison, bias was also calculated for Eq. (1) for all age and height classes. Across both classes (height and age), estimates of bias in stand height and its standard deviation were very small for both models. However, overall bias and the standard deviation were smaller for Eq. (2) than for Eq. (1).

To predict future stand height under a changing climate, white spruce stand heights were estimated using Eq. (2) for three randomly selected locations in northeastern (near Kapuskasing), northwestern (north of Kenora), and southern

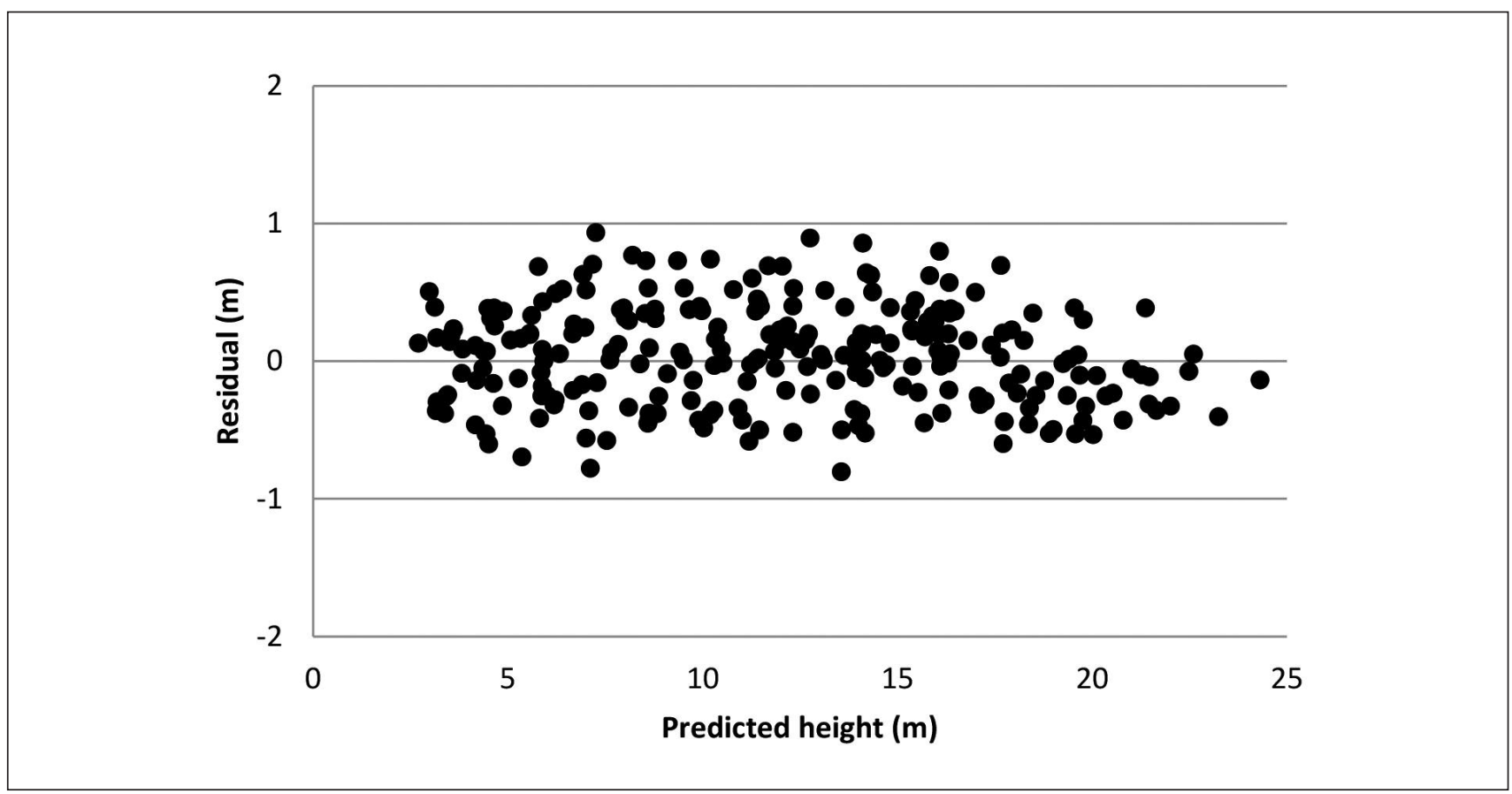

Fig. 2. Residuals (observed - predicted) in predicting heights of white spruce using Equation (2). 
(a)

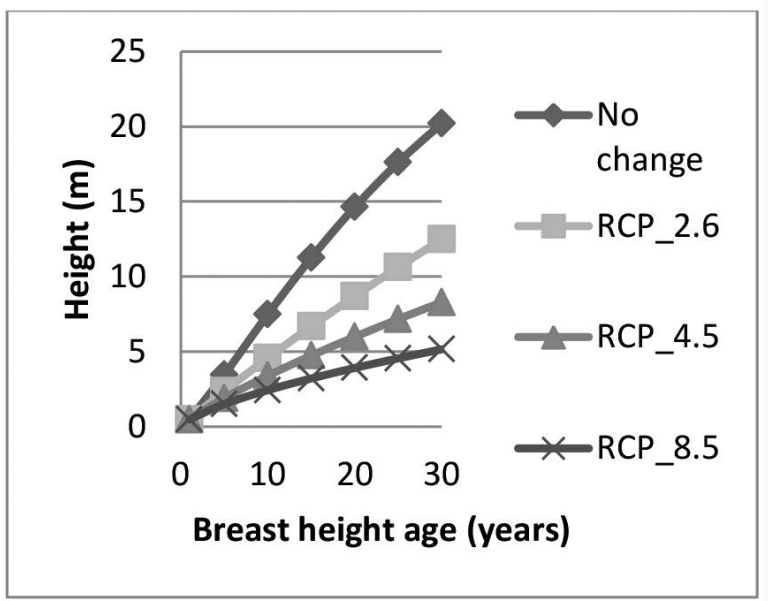

(c)

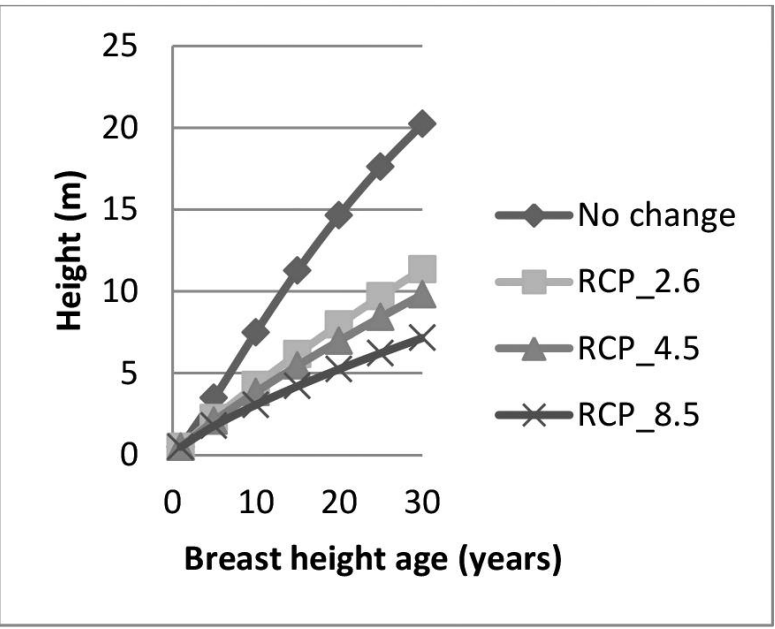

(b)

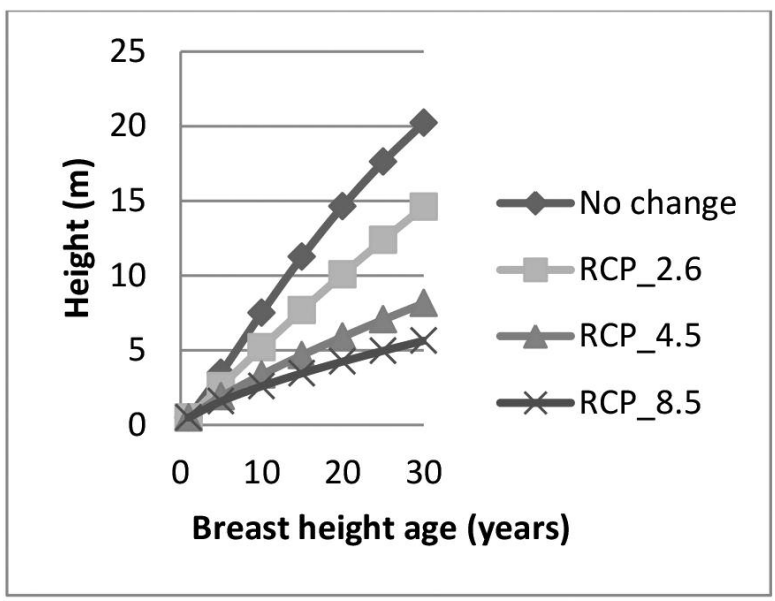


Table 5. Current and projected values of climate variables (warmest quarter mean temperature (WQMT) and warmest quarter total precipitation (WQMT)] for northeastern, northwestern, and southern locations in Ontario used for site index evaluation. Climate variables for the period 2041 to 2070 were projected using three emission trajectories known as Representative Concentration Pathways (RCPs).

\begin{tabular}{|c|c|c|c|c|c|c|c|}
\hline \multirow[b]{2}{*}{$\begin{array}{l}\text { Climate } \\
\text { scenario }\end{array}$} & \multirow[b]{2}{*}{$\begin{array}{l}\text { Growth } \\
\text { period }\end{array}$} & \multicolumn{2}{|c|}{ Northeast } & \multicolumn{2}{|c|}{ Northwest } & \multicolumn{2}{|c|}{ South } \\
\hline & & $\begin{array}{c}\text { WQMT } \\
\left({ }^{\circ} \mathrm{C}\right)\end{array}$ & $\begin{array}{c}\text { WQTP } \\
(\mathbf{m m})\end{array}$ & $\begin{array}{c}\text { WQMT } \\
\left({ }^{\circ} \mathrm{C}\right)\end{array}$ & $\begin{array}{l}\text { WQTP } \\
(\mathrm{mm})\end{array}$ & $\begin{array}{l}\text { WQMT } \\
\left({ }^{\circ} \mathrm{C}\right)\end{array}$ & $\begin{array}{c}\text { WQTP } \\
(\mathrm{mm})\end{array}$ \\
\hline Current & 1971-2013 & 15.7 & 241 & 16.2 & 235 & 15.9 & 266 \\
\hline RCP 2.6 & $2041-2070$ & 17.6 & 216 & 19.8 & 271 & 20.3 & 258 \\
\hline RCP 4.5 & $2041-2070$ & 18.6 & 201 & 21.0 & 244 & 20.9 & 257 \\
\hline RCP 8.6 & $2041-2070$ & 19.7 & 185 & 22.2 & 238 & 22.3 & 258 \\
\hline
\end{tabular}

(27.8\%) and eastern (74.4\%) Ontario locations under RCPs 2.6 and 8.5, respectively. At age 30, stand heights at the eastern location were shorter by $38.2 \%, 58.9 \%$, and $74.4 \%$ for the 2.6, 4.5, and 8.5 RCPs scenarios, respectively, relative to those under current climate. At the western location, stand heights were $27.8 \%, 59.7 \%$, and $72.1 \%$ shorter, respectively. Similarly, at the southern location, stand heights were $43.8 \%, 51.5 \%$, and $64.6 \%$ shorter, respectively.

Finally, stand height over age curves were generated using Eq. (1) for the observed range of site productivity of white spruce stands (Fig. 4). To generate these curves, stand heights at the index age of 25 years were used as site indices. These curves were logically consistent in the way they are observed and realistic across all productivity classes.

As Clutter et al. (1983) stated, the productivity of a site depends on environmental conditions (biotic, edaphic, and climatic) at a particular location. Similarly, Latta et al. (2010) mentioned that forest productivity is directly influenced by changes in temperature and precipitation regimes. Our results indicate that climate variables (temperature and precipitation) are important drivers of site productivity. These variables could be incorporated in existing stand height models to make them climate sensitive. This can be accomplished, at least in the McDill-Amateis growth function, by expressing the parameters (often referred to as the asymptote and rate parameters) in terms of climate variables.

In the case of white spruce, climatic variables WQMT and WQTP were significant in explaining variation in stand height. These are very intuitive climate variables that can be easily interpreted in explaining the growth of any tree species. The fit statistics of the stand height model improved significantly when climate variables were included.

These results are consistent with the findings of previous studies. Wang et al. (2007) and Bravo-Oviedo et al. (2008) reported that including climate variables improved the fit and predictive accuracy of dominant height and site index models of Eucalyptus globulus Labill. plantations in southeastern Australia and Mediterranean maritime pine (Pinus pinaster Ait.) in eastern Spain, respectively. However, they did not evaluate whether the changes in climate had negative or positive effects. Newton (2012) reported that jack pine yields on low to medium quality sites would largely be unaffected by climate change by the end of a 60-year growth period (2011-

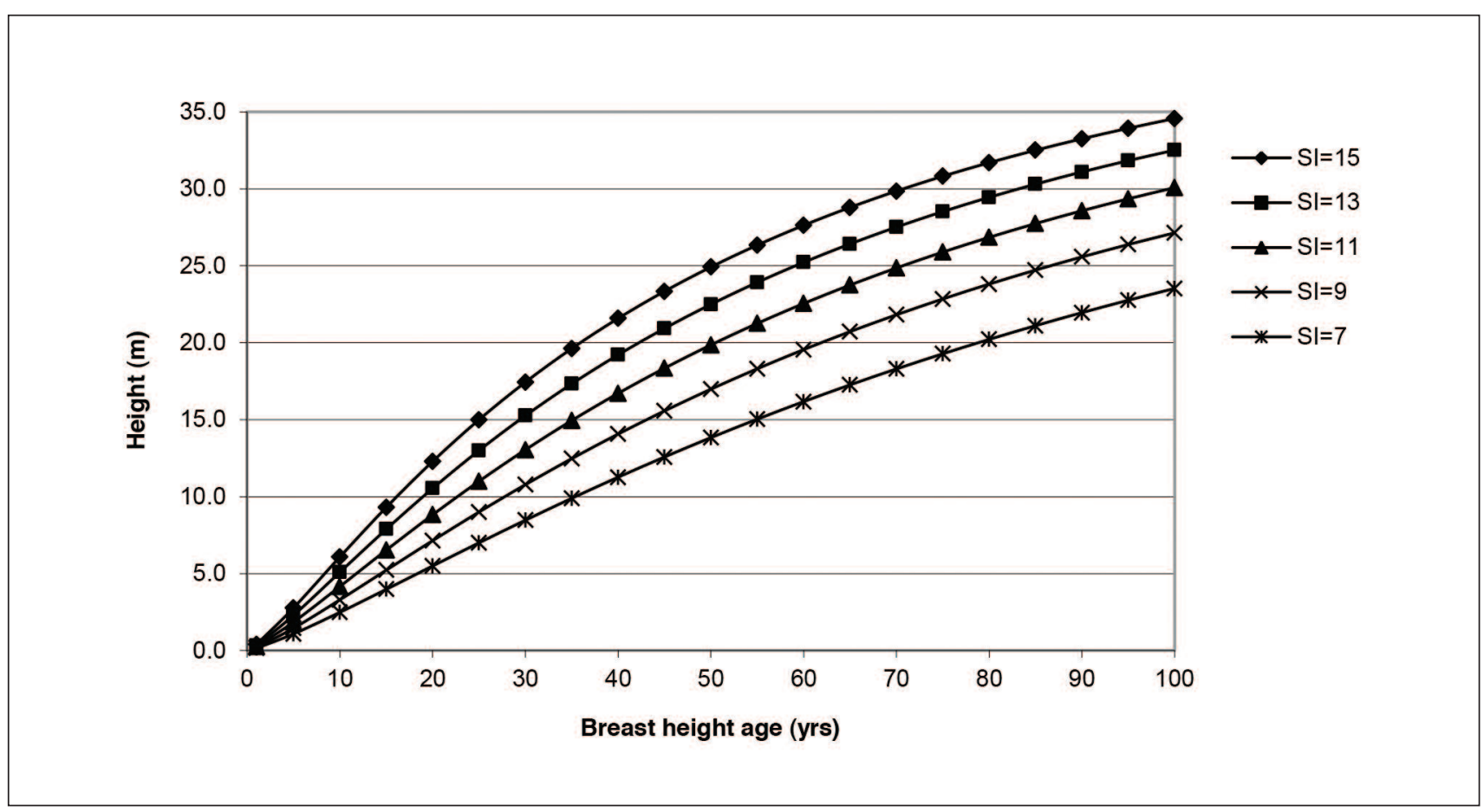

Fig. 4. Stand height/site index $\left(\mathrm{SI}_{(25)}\right)$ profiles generated using Equation (1) for plantation-grown white spruce trees in Northern Ontario for the range of site productivity. 
2070) but that the mean dominant height growth on good to excellent quality sites would be reduced by $6.6 \%$ and $12 \%$ under the B1 and A2 scenarios, respectively. Similarly, Sharma et al. (2015) reported reduced stand height growth for jack pine and black spruce under scenarios of changing climate. Under the A2 scenario, they projected that at age 30 stand heights would be 16 and $28 \%$ shorter for jack pine and black spruce, respectively, relative to those under the current climate. Under the B2 scenario, stand heights were $2 \%$ and $16 \%$ shorter, respectively, at age 30 .

Recently, Sharma and Parton (In press) investigated the effects of climate on stand height of red pine plantations in Ontario. They found that height growth decreased significantly after a 30-year growth period (2041 to 2070), with reductions varying by region and climate change scenario. Stand heights in the northeast were shorter by $15.0 \%$ and $35.0 \%$ for the 2.6 and 8.5 RCPs scenarios, respectively, relative to those for the current climate scenario. Stand heights in the south were shorter by $32.8 \%$ and $48.4 \%$, respectively, for the same scenarios. Effects in the northwest were intermediate between those in the northeast and south.

With models developed by expressing SI directly in terms of climate variables, Albert and Schmidt (2010) found that biophysical variables (latitude, longitude, soil, and climate) explained 39 and $34 \%$ of SI variability in Norway spruce (Picea abies (L.) Karst.) and common beech (Fagus sylvatica L.), respectively. Weiskittel et al. (2011) reported that $68 \%$ of the variability in SI was accounted for by climate-related variables across western U.S. forests. However, the variation in SI explained by climate and site variables in this study for white spruce was about $33 \%$.

\section{Conclusions}

Site and climatic effects on site productivity of white spruce plantations were analyzed by regressing site index against site and climate variables. The site and climate variables explained $33 \%$ of the variability in site productivity estimates. Stand height models were developed by incorporating climate variables in the models. Climate variables that were significant in explaining the variation in stand height of white spruce were total precipitation and mean temperature of the warmest quarter. Fit statistics of the stand height model were improved by the addition of climate variables. The pseudo $\mathrm{R}^{2}$ for the stand height models was greater than $97 \%$.

Stand heights were predicted for three randomly selected locations (in eastern, western, and southern Ontario) for the period 2041 to 2070 under three emissions trajectories known as Representative Concentration Pathways (RCPs). At the end of the 2041-2070 growth period, projected heights under all climate change scenarios were shorter than those under current climate change. The difference in height from the current climate was more pronounced in the south than in the east and west under the 2.6 RCPs and in the east and west than in the south under the 8.5 RCPs scenario.

The models developed here can be used to estimate stand height at any age within the range of ages of this study, given the height at a point in time and the relevant climate variables, thereby supporting more informed forest management decisions. In addition, stand height estimated at the base age will provide the SI value. Therefore, the models can also serve as SI models. However, caution should be applied in using the model with climate variables as the actual future climate change scenario is still unknown. As well, when climate variables are unavailable, the model fitted to only the height-age pair data can be used as a stand height/SI model for white spruce plantations.

\section{Acknowledgements:}

This study was supported by the Ontario Ministry of Natural Resources and Forestry and its Climate Change Program. The authors are grateful to Daniel McKenney and Pia Papadopol, Canadian Forest Service, for providing estimates of climate variables for study sites, Lisa Buse, Ontario Forest Research Institute, for editing an earlier version of this manuscript, and the anonymous reviewers and associate editor for their constructive and insightful review comments.

\section{References}

Akaike, H. 1978. A Bayesian analysis of the minimum AIC procedure. Annals of the Institute of Statistical Mathematics 30: 9-14. Albert, M. and M. Schmidt. 2010. Climate-sensitive modelling of site-productivity relationships for Norway Spruce (Picea abies (L.) Karst.). Forest Ecol. Manag. 259: 739-749.

Bravo-Oviedo, A., M. Tomé, F. Bravo, G. Montero and M. del Rio. 2008. Dominant height growth equations including site attributes in the generalized algebraic difference approach. Can. J. Forest Res. 38: 2348-2358.

Burkhart, H.E. and R.B. Tennent. 1977. Site index equations of radiata pine in New Zealand. N. Z. J. Forest Sci. 7: 408-416.

Burkhart, H.E. and M. Tome. 2012. Modeling Forest Trees and Stands. Springer, Dordrecht. 457 p.

Carmean, W.H. and D.J. Lenthall. 1989. Height-growth and site index curves for jack pine in north central Ontario. Can. J. Forest Res. 19: 215-224.

Cieszewski, C.J. 2003. Developing a well-behaved dynamic site equation using a modified Hossfeld IV function $\mathrm{Y}^{3}=$ $\left(\mathrm{ax}^{\mathrm{m}}\right) /\left(\mathrm{c}+\mathrm{x}^{\mathrm{m}-1}\right)$, A simplified mixed-model and scant subalpine fir data. Forest Sci. 49: 539-554.

Clutter, J.L., J.C. Fortson, L.V. Pienaar, G.H. Brister and R.L. Bailey. 1983. Timber Management: A Quantitative Approach. Krieger Publishing Company, Malabar, FL.

Colombo, S.J., D.W. McKenney, K.M. Lawrence and P.A. Gray. 2007. Climate change projections for Ontario: A practical guide for policymakers and planners. Ontario Ministry of Natural Resources, Applied Research and Development Branch, Peterborough, Ontario Climate Change Research Report. CCRR-05. Diéguez-Aranda, U, H.E. Burkhart and R.L. Amateis. 2006. Dynamic site model for loblolly pine (Pinus taeda L.) plantations in the United States. Forest Sci. 52: 262-272.

Garcia, O. 2005. Comparing and combining stem analysis data and permanent sample plot data in site index models. Forest Sci. 51: 277-283.

Goelz, J.C.G. and T.E. Burk. 1992. Development of well-behaved site index equations: jack pine in north central Ontario. Can. J. Forest Res. 22: 776-784.

Graves, H.S. 1906. Forest Mensuration. John Wiley \& Sons, New York, NY. 458 p.

IPCC. 2000. [Intergovernmental Panel on Climate Change]. Emissions Scenarios. Special Report of the Intergovernmental Panel on Climate Change, [Nakicenovic, N., J. Alcamo, G. Davis, B. de Vries, J. Fenham, S. Gaffin, K. Gregory, A. Grübler, T.-Y. Jung, T. Kram, E.L. La Rovere, L. Michaelis, S. Mori, T. Morita, W. Pepper, H. Pitcher, L. Price, K. Riahi, A. Reohrl, H.H. Rogner, A. Sankovski, M. Schlesinger, P. Shukla, S. Smith, R. Swart, S. van Rooijen, N. Victor, and Z. Dadi, (eds)]. Cambridge University Press, Cambridge, UK. $570 \mathrm{p}$.

Latta, G., H. Temesgen, D. Adams, and T. Barrett. 2010. Analysis of potential impacts of climate change on forests of the United States Pacific Northwest. Forest Ecol. Manag. 259: 720-729. 
Littell, R.C., G.A. Milliken, W.W. Stroup, R.D. Wolfinger and O. Schabenberger. 2006. SAS for mixed models. SAS Institute, Cary, NC. 814 p.

Mamo N. and H. Sterba. 2006. Site index functions for Cupressus lusitanica at Munesa Shashemene, Ethiopia. Forest Ecol. Manag. 237: 429-435.

McKenney, D.W., M.F. Hutchinson, P. Papadopol, K. Lawrence, J. Pedlar, K. Campbell, E. Milewska, R.F. Hopkinson, D. Price and T. Owen. 2011. Customized Spatial Climate Models for North America. B. A. Meteorol. Soc. 92: 1611-1622. doi: http://dx.doi.org/ 10.1175/2011BAMS3132.1

Mekis, É. and L.A. Vincent. 2011. An overview of the second generation adjusted daily precipitation dataset for trend analysis in Canada. Atmosphere-Ocean 49: 163-177.

Meng, S.X., S. Huang, Y. Yang, G. Trincado and C.L. VanderSchaaf. 2009. Evaluation of population-averaged and subject-specific approaches for modelling the dominant or co-dominant height of lodgepole pine trees. Can. J. Forest Res. 39: 1148-1158.

Newton. P. 2012. Simulating site-specific effects of a changing climate on jack pine productivity using a modified variant of the CROPLANNER model. Open Journal of Forestry 2(1): 23-32.

SAS Institute Inc. 2004. SAS Institute Inc. Cary, NC, USA.

Sharma, M. and J. Parton. (In press). Climatic effects on site productivity of red pine plantations. Forest Sci.

Sharma, M., R.L. Amateis and H.E. Burkhart. 2002. Top height definition and its effect on site index determination in thinned and unthinned loblolly pine plantations. Forest Ecol. Manag. 168: 163-175.
Sharma, M., N. Subedi, M. TerMikaelian and J. Parton. 2015. Modeling climatic effects on stand height/site index of plantationgrown jack pine and black spruce trees. Forest Sci. 61: 25-34.

Subedi, N. and M. Sharma. 2010. Evaluating height-age determination methods for jack pine and black spruce plantations using stem analysis data. North. J. Appl. For. 27: 50-55.

Subedi. N. and M. Sharma. 2011. Individual-tree diameter growth model for black spruce and jack pine plantations in northern Ontario. Forest Ecol. Manag. 261: 2140-2148.

Subedi, N. and M. Sharma. 2013. Climate-diameter growth relationships of black spruce and jack pine trees in boreal Ontario, Canada. Global Change Biol. 19(2): 505-516.

Trincado, G. and H.E. Burkhart. 2006. A generalized approach for modeling and localizing stem profile curves. Forest Sci. 52: 670-682. Vanclay, J.K. 1994. Modelling forest growth and yield: applications to mixed tropical forests. CAB International, Oxon, UK. 312 p.

Vincent, L. A., X. L. Wang, E. J. Milewska, H. Wan, F. Yang and V. Swail. 2012. A second generation of homogenized Canadian monthly surface air temperature for climate trend analysis. J. Geophys. Res. Atmosph. 117: doi: 10.1029/2012JD017859.

Wang, Y., V.M. LeMay and T.G. Baker. 2007. Modelling and prediction of dominant height and site index of Eucalyptus globulus plantations using a nonlinear mixed-effects model approach. Can. J. Forest Res. 37: 1390-1403.

Weiskittel, A.R, N.L. Crookston and P.J. Radtke. 2011. Linking climate, gross primary productivity, and site index across forests of the western United States. Can. J. Forest Res. 41: 1710-1721. 